\title{
Vijeće predstavnika nacionalnih sestrinskih udruga i Kongres Međunarodnog vijeća medicinskih sestara (ICN)
}

U Barceloni je od 25.-27. svibnja 2017. održana sjednica najvišeg upravljačkog tijela ICN-a, Vijeće predstavnika nacionalnih sestrinskih udruga, a od 27. svibnja do 1. lipnja Kongres ICN-a na kojem je sudjelovala Hrvatska udruga medicinskih sestara (HUMS). Annette Kennedy, treća dopredsjednica ICN-a u mandatu 2013.-2017. i predsjednica Europske udruge medicinskih sestara (EFN) od 2005.-2007. izabrana je za 28. predsjednicu ICN-a. Nova predsjednica ICN-a dolazi iz Irske s bogatim iskustvom u političkim problemima vezanim uz sestrinstvo na visokoj razini koje je stekla dugogodišnjim radom u ICN-u i EFN-i te 19-ogodišnjim radom kao voditeljica profesionalnog razvoja u Irskoj udruzi medicinskih sestara i primalja. Njezin rad obilježen je njenim doprinosom u napretku sestrinstva posebice kroz Centar za profesionalni razvoj u Dublinu, gdje je pomogla uspostaviti istraživačku i obrazovnu mrežu.

„Vjerujem da ICN može globalno utjecati na pružanje zdravstvene njege i zdravstvenu politiku. U sljedeće četiri godine nastojat ću osigurati da ova svjetska organizacija ima svoju svrhu u promjenjivoj ekonomskoj i zdravstvenoj okolini, zadovoljavajući potrebe naših članova i omogućavajući im da oni zadovolje potrebe pacijenata u svojim zemljama.", izjavila je novoizabrana predsjednica.

Uz predsjednicu, izabrali i smo i 13 novih članova Upravnog odbora na mandat od 4 godine koji predstavljaju 7 regija:

1. Thembeka Gwagwa (Južna Afrika) - Regija 1

2. Fatima Al Rifai (Ujedinjeni Arapski Emirati) - Regija 2

3. Ioannis Leontiou (Cipar) - Regija 2

4. Karen Bjoro (Norveška) - Regija 3

5. Brigita Skela-Savič (Slovenija) - Regija 3

6. Roswitha Koch (Švicarska) - Regija 4

7. Maria Eulalia Juvé (Španjolska) - Regija 4

8. Pamela Cipriano (SAD) - Regija 5

9. Lisa Little (Kanada) - Regija 5

10. Erika Caballero (Čile) - Regija 6

11. Lian-Hua Huang (Tajvan) - Regija 7

12. Sung Rae Shin (Koreja) - Regija 7

13. Wu Ying (Kina) - Regija 7

HUMS je dio Regije 3, a ove godine oprostili smo se od predstavnika naše regije, kolege Petera Požuna i poželjeli dobrodošlicu našoj novoj predstavnici Brigiti Skeli Savić. Veselimo se budućoj suradnji s našim dragim kolegama iz Slovenije.

Od srca čestitamo novoj predsjednici i članovima Upravnog odbora te im želimo uspješan rad u novom sastavu!

Kongres ICN-a otvoren je u Palau Sant Jordi svečanim ulaskom predstavnika nacionalnih sestrinskih udruga, članica ICN-a. Na Kongresu je sudjelovalo više od 8.000 medicinskih sestara iz više od 130 zemalja svijeta. Tijekom četiri dana programa, predstavljeni su problemi medicinskih se-

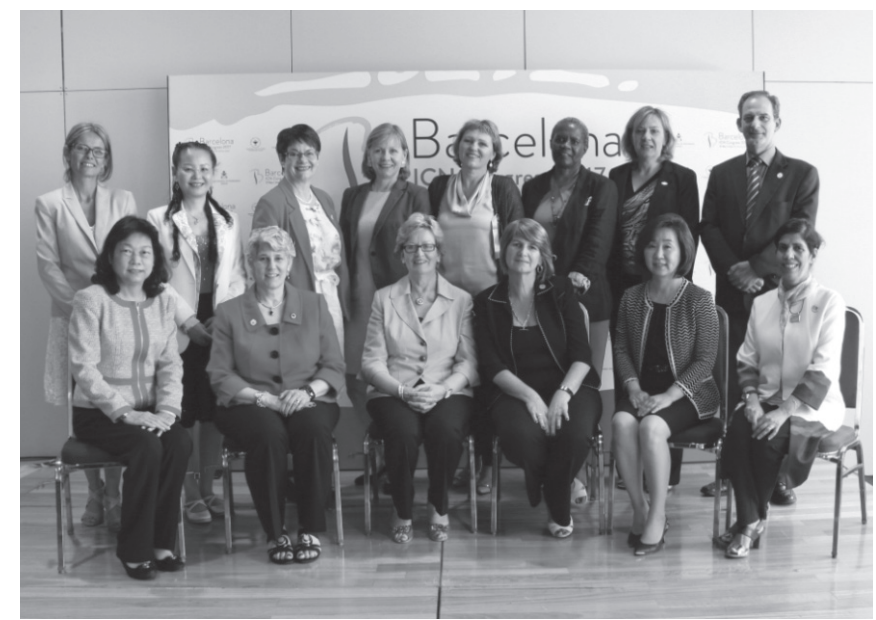

stara u svijetu. Veliki naglasak bio je na edukaciji medicinskih sestara i osnaživanju sestrinske uloge u zdravstvenoj politici. U središtu rasprava bila je i inovativna primarna zdravstvena njega te izazovi koji se pojavljuju s porastom globalizacije koja izaziva nove zdravstvene probleme, a medicinske sestre su te koje su najprimjerenije za njihovo rješavanje. Jedan od elaborata u Velikoj Britaniji (All Party Parliamentary Group - APPG) o utjecaju medicinskih sestara istaknuo je da razvoj sestrinske profesije utječe na postizanje globalnih ciljeva, jer medicinske sestre čine polovicu radne snage, a razvojem sestrinske profesije poboljšava se zdravlje te promiču ekonomija i jednakost među spolovima. Također je istaknut značaj ICN-a i sestrinskih udruga članica pri postizaznju navedenih ciljeva.

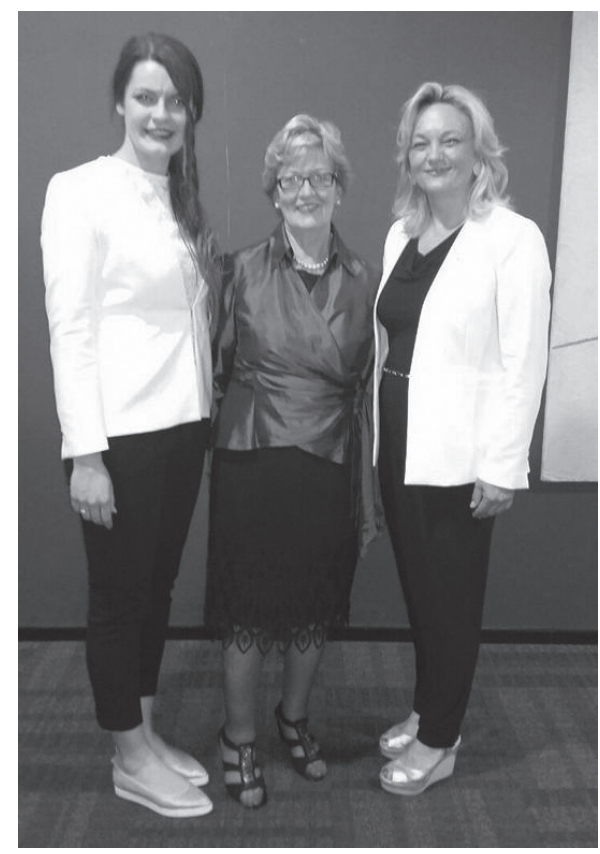


Kongres je osim predavanja bio prožet i panel raspravama i okruglim stolovima te poster prezentacijama. Medicinske sestre najbolje poznaju zdravstveni sustav i zajedno s ostalim zdravstvenim djelatnicima brinu o zdravlju pacijenata i upravo zato trebaju zagovarati bolje radne uvjete, uvjete zdravstvene njege i timski rad. Naposljetku, glavna izvršna direktorica, dr. Frances Hughes predstavila je viziju budućnosti ICN-a u kojoj su tehnologija, politika, partnerstvo i dobra komunikacija ključni elementi ICN-ove reforme za budućnost.

Na zatvaranju Kongresa objavljen je sljedeći Kongres ICNa, koji će se održati u Singapuru 2019., a dvije godine nakon toga u Abu Dhabiju. Više o idućem Kongresu možete pogledati na: $h t t p: / / w w w . i c n . c h / i m a g e s /$ stories/documents/ news/press_releases/PR_27_2019_2021_Congresses.pdf

\section{Literatura/References:}

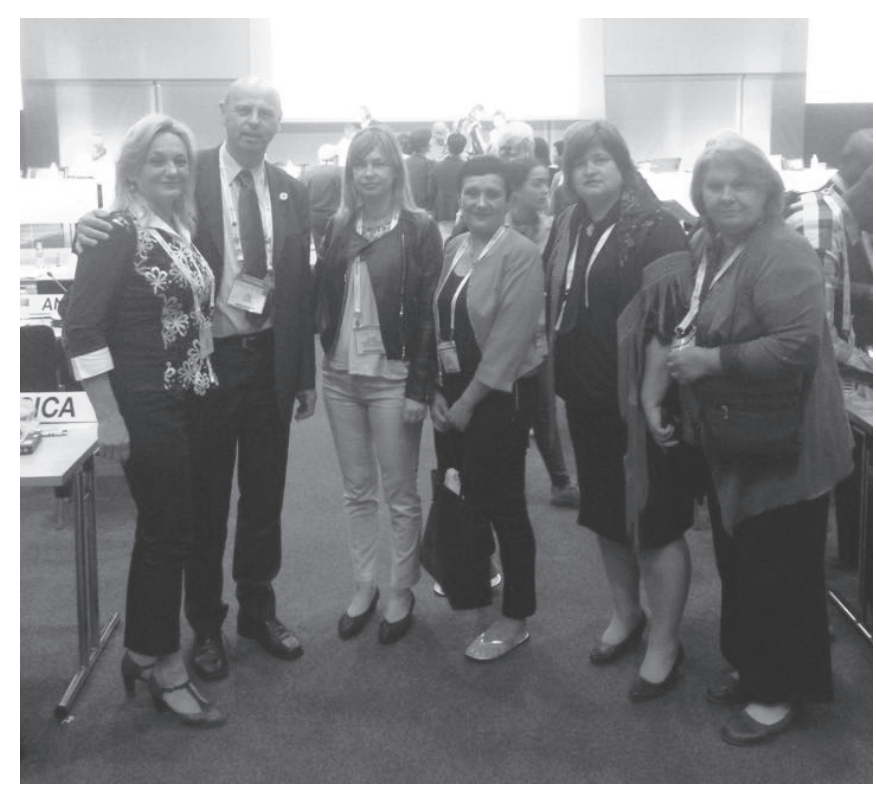

[1] www.icn.ch 